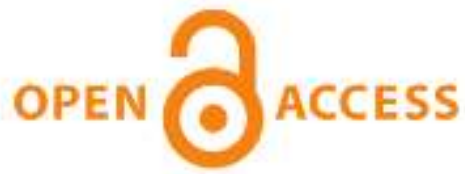

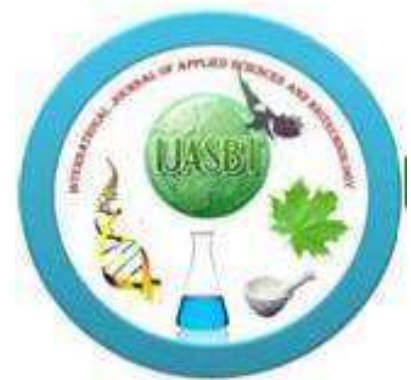 \\ International Journal of Applied Sciences and Biotechnology
}

\author{
A Rapid Publishing Journal
}

ISSN 2091-2609

\section{Indexing and Abstracting}

CrossRef, Google Scholar, Global Impact Factor, Genamics, Index Copernicus, Directory of Open Access Journals, WorldCat, Electronic Journals Library (EZB), Universitätsbibliothek Leipzig, Hamburg University, UTS (University of Technology, Sydney): Library, International Society of Universal Research in Sciences (EyeSource), Journal Seeker, WZB, Socolar, BioRes, Indian Science, Jadoun Science, JourInformatics, Journal Directory, JournalTOCs, Academic Journals Database, Journal Quality Evaluation Report, PDOAJ, Science Central, Journal Impact Factor, NewJour, Open Science Directory, Directory of Research Journals Indexing, Open Access Library, International Impact Factor Services, SciSeek, Cabell's Directories, Scientific Indexing Services, CiteFactor, UniSA Library, InfoBase Index, Infomine, Getinfo, Open Academic Journals Index, HINARI, etc.

\section{CODEN (Chemical Abstract Services, USA): IJASKD}

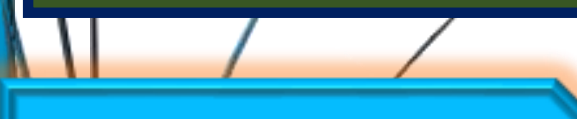

Vol-3(2) June, 2015

\section{Available online at:}

http://www.ijasbt.org

$\&$

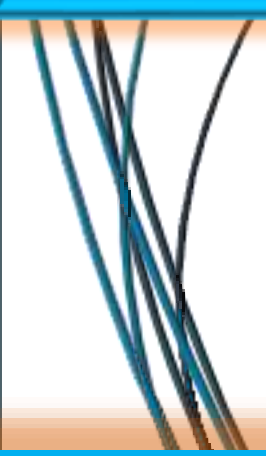

Impact factor*: $\mathbf{1 . 4 2 2}$

Scientific Journal Impact factor": 3.419

SEM-Biotech

Publishing 


\title{
ANTIOXIDANT ACTIVITY OF LUPINE SEEDS IN NILE TILAPIA FISH $(O$. NILOTICUS) SUSPECTED TO OXIDATIVE STRESS INDUCED BY NEEMAZAL T/S
}

\author{
Ashraf A El-Badawi \\ Central Lab for Aquaculture Res Abbassa Abo-Hammad, Sharkia,Egypt. \\ Biological Department, University College,Umm Al-Qura Univ.,Kingdom of Saudi Arabia. \\ *Corresponding author email: badawi_ashraf@live.com
}

\begin{abstract}
This study was designed to determine the effects of acute toxicity of NeemAzal T/S on Nile tilapia (Oreochromis niloticus) and to investigate the antioxidant effect of Lupine seeds on the gills and erythrocytes(EC) oxidative stress induced by NeemAzal T/S in Nile tilapia .Two doses of NeemAzal; 1/10 LC50:16 PPM (NA1) and 1/5 LC50:32 PPM (NA2) and three periods of 10, 20 and 30 days were used. Oxidative stress parameter, total peroxide (TP) and antioxidant enzyme activities, catalase (CAT) and superoxide dismutase (SOD) as well as glycemia were measured. NA2 markedly decreased CAT and SOD activities in gills and erythrocytes at most periods, but NA1 had less effect. In turn, both doses significantly enhanced TP levels in gills and EC. Moreover, hyperglycemia was detected 30 days after control (NA) exposure. LS significantly curtailed or abolished the adverse effect of NA exposure on oxidative and antioxidant parameters in gills and EC. This may be attributed to the hypoglycemic effect of LS as well as its antioxidant efficiency. In conclusion, Lupine seed exerts a potent antioxidant activity against oxidative damages induced by NeemAzal T/S in Nil tilapia fish.
\end{abstract}

Key Words: Fish, NeemAzal T/S, Lupine, oxidative stress, gills and erythrocytes.

\section{Introduction}

Fish is directly affected by different pesticides (Rao and Pillala, 2001). These effects have been observed in almost all parts of the fish body and systems (Sana and Mohammad, 2015). Pesticides induce different types of toxicity in fish, which these pesticides lead to, such as changes in haematological changes (Saeedi et al., 2012; Ullah et al., 2014), histopathological disturbances (Deka and Mahanta, 2012; David and Kartheek, 2014) and changes in antioxidant defence system (Nwani etal., 2010; Muthukumaravel et al., 2013). Worldwide, there are over 100 commercial neem formulations such as Margosan-O, Bio-neem, Azatin, Neemies, Safer's ENI, Wellgro, RDRepelin, Neemguard, Neemark and Neemazal. Neem derivatives have been applied against pests as leaves, oil, cake, extracts and as formulations in neem oil (Hanem, 2012).

Mondal et al., (2007) had reported that such pesticides may reach the water system causing harm to fish as well as aquatic fauna .So there is trend worldwide to use herbal pesticides (biopesticides) like Neem instead of the chemical ones. The application of neem extract (bio-pesticides) for the control of unwanted organisms in agricultural farms are much safer and more environmental friendly than synthetic pesticides (Reza and Gholamreza, 2012). Neem-On extract is less toxic to Indian major carps Labeo rohit, than other synthetic insecticides used in fish-farming (Bhat et al., 2012). The acute toxicity values of several Neem preparations and some for pure azadirachtin for laboratory animals and some non-target species have been studied extensively (Patil et al., 2011; Saravanan et al., 2011; Salman et al., 2013).

Non-aqueous extracts appear to be the most toxic Neembased products and suggested that use of Neem derived pesticides as an insecticide should not be discouraged (Boeke et al., 2004). NeemAzal T/S is approved as an insecticide in organic agriculture in the European Union. In the Czech Republic, a standardised variant of NeemAzal $\mathrm{T} / \mathrm{S}$ with $1 \%$ of the active ingredient, azadirachtin, is authorised for use in pest control in potatoes (against Colorado potato beetle) and pear and apple trees (against aphids) ) (Chromcova et al., 2015).

Also, Fish gills showed histological alterations including hyperplasia of the epithelial cells and epithelial lifting in response to toxic exposure (Elenka Georgieva et al., 2014). Gills therefore are potentially useful to monitor the health of fish (Palaniappan et al., 2010).

The pollution of water with Neem may induce hypoxia resulting in decreased oxygen- uptake of the gills making the fish less able to get adequate oxygen for its metabolic activity (Winkaler et al., 2007). Long exposure of Tilapia 
zillii to low concentrations of crude extract of A.indica (Neem) delayed the growth and caused respiratory problems (Omoregie and Okpanachi, 1992). Fish exposed to all neem extract concentrations exhibited damaged gill tissue, thereby reducing the oxygen consumption and disrupting the osmoregulatory function of aquatic organisms (Elissandra et al., 2007).

It is possible that the leakage of ROS from RBC involves $\mathrm{Hb}$ binding to band 3 of the red cell membrane (Lushchak, 2011; Stara et al., 2012). In hypoxia, red blood cells produces reactive oxygen species that diffuse to endothelial cells of blood vessels (Kiefmann et al., 2008). Additionally, in hypoxia, increased $\mathrm{Hb}$ autoxidation augments superoxide production in RBCs. Consequently, RBCs release $\mathrm{H}_{2} \mathrm{O}_{2}$ and may allow the erythrocytes vulnerable to oxidative damage (Jain et al., 1993). Most studies of Neem pesticide on fish were focused on fish mortality, determination of $\mathrm{LC}_{50}$ estimation of number of RBCs, hematocrit and hemoglobin (Davoodi and Abdi, 2012; Kumar et al., 2013). Oxidative stress arises when there is an imbalance between radicalgenerating and radical-scavenging activity; it may therefore cause an increase in the formation of oxidation products (Gutteridge, 1995). There is no literature concerning the effect of Neem oil on the oxidative stress on fish particularly on erythrocytes and gills in fresh water fish which usually found near the agriculture areas and polluted irrigated water.

Lupine seeds may have higher antioxidant activity in lipidsoluble substances (Boateng et al., 2008; Pastor et al., 2010). The digestion of legume protein resulted in high amount of arginine, aspartate and glycine. The amino acid arginine could ameliorate the oxidative stress in alloxantreated rats (El-Missiry et al., 2004). Also, Alpha-, gammaand delta-tocopherols were found in the lupine oil antioxidant activity was found both in the flours and in the hulls (Li et al., 2007). It was found that aqueous suspension of lupine seeds have a prophylactic effect against prolonged hyperglycemia and its damaging effect on the kidney of the fish Clarias gariepinus (Al-Salahy and Mahmoud, 2004).

This study aimed to determine the acute toxicity effects of NeemAzal - T/S on Nile tilapia Oreochromis niloticus and evaluate the ability of lupine seeds to counteracting NAinducing oxidative stress in gills and RBCs in Oreochromis niloticus by monitoring of total peroxide as destructive bioindicator and activities of catalase and superoxide dismutase as antioxidants. Also, to highlight some physiological mechanism of toxicity of NeemAzal and the probable recovery by lupine.

\section{Materials and Methods}

Determination of 96 hours half-lethal concentration dose (LC50) for NeemAzal - T/S:

Preliminary screening was carried out to estimate the concentration of the used insecticide, which is most likely to cause $50 \%$ mortality (LC50) for 96 hours exposure to determine the appropriate testing range of concentration for NeemAzal- T/S. This task was done according to the procedure described by EPA (1985). One hundred and ten healthy fishes (weighing of $5.02 \pm 1.2 \mathrm{~g}$ and length of $6.42 \pm 0.43 \mathrm{~cm}$ ) were distributed in eleven aquaria with 100 liter capacity (ten fish for each aquarium). The aquaria were supplied with dechlorinated tap water, kept at constant aeration, temperature and $\mathrm{pH}$. The fish were not fed $24 \mathrm{~h}$ before and during the experiment. Ten concentration of NeemAzal was distributed in the aquaria $(25,50,75$, $100,125,150,175,200,225$ and $250 \mathrm{mg} / \mathrm{l})$. The aquarium number 11 was kept as control. All fish were observed for 96 hours to record the number of dead and active fish in each aquarium.

The 96-hr LC50 was calculated according to the following equation:

LC50 $=$ highest dose $-\Sigma \mathrm{ab} / \mathrm{n}$,

where:

a: is a constant factor between two successive concentrations.

$\mathrm{b}$ : is the mean of dead fish in two successive groups.

$\mathrm{n}$ : is the number of fish in each group (10 fish).

\section{Fish and Materials}

Healthy sixty six fish Tilapia (O. niloticus) of both sexes weighing $32-38 \mathrm{~g} /$ fish $(12-15 \mathrm{~cm}$ length) were collected from the nursery ponds of El-Jomoom Fish Farm, Jeddah, Kingdom of Saudi Arabia. On arrival at the laboratory, fishes were immediately released into special five glass tanks (Aquaria) $(40 \times 70 \times 60)$ containing tap water and then maintained there for 10 days for acclimatization condition. The fish groups were three (Table 1). The first one was subdivided into three subgroups exposed to NeemAzal T/S (NA) for 10 days; control, low dose (NA1) and high dose (NA2). The second group was also subdivided into three subgroups exposed to NA for 20 days; control, NA1 and NA2. The third group was subdivided into five subgroups exposed to NA for 30 days: control, NA1, NA2, NA1+ lupine supplementation (LS) and NA2 + LS. The number of each fish subgroup was six. Air compressor was used for oxygenation of water. Dissolved oxygen concentrations

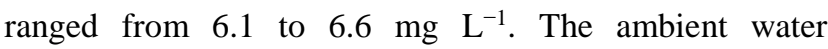
temperature was ranged between $20-23{ }^{\circ} \mathrm{C}$; $\mathrm{pH}$ was ranged between 7.1-7.4. All fish were fasted for the last $12 \mathrm{~h}$ of the experiment. The water medium was changed at 24 hours interval to remove the metabolic-pollutants with the same treatments according to the experimental protocol. Portable oxygen meter (DO-980) and Hanna Instrument HI 2210 Bench top PH meter W/Temperature Compensation meter were used.

Fish were fed on artificial feed twice daily a total of $2 \%$ of mean body weight of dry pellets of $2.5 \mathrm{~mm}$. Food ratio of 
dry weight composed of $40 \%$ fish meal, $18 \%$ fat, $10 \%$ corn starch, $11 \%$ ashes.

\section{Lupine Seed Preparation}

Seeds of lupine (Lupinus termis) were washed, kept in the incubator at $37^{\circ} \mathrm{C}$ to dryness for $24 \mathrm{~h}$ and ground well, and then lupine powder was added by $5 \%$ to the paste of normal ratio of fish diet before dryness. This food containing lupine was prepared to be tested as antioxidant effect as well as against oxidative stress in fish treated with bioinsecticide; Neemazal of different doses and durations.

\section{NeemAzal-T/S}

One of the most promising produced neem products. The active ingredient is Azadirachtin (1\%), in addition to plant oil and emulsifier ( Troß etal., 1998 ). The recorded 96-h LC50 of NeemAzal-T/S for the freshwater fish was 160 PPM (Stewart, 1998). Therefore, the used NeemAzal-T/S doses used in this experiment were 1/5 LC50 (32 PPM: high dose) and 1/10 LC50 (16 PPM: low dose). Before use, the were lysed in nine volumes of ice-cold distilled water to prepare a $10 \%$ erythrocyte hemolysate. All samples were $250 \mu \mathrm{L}$-aliquotted into Eppindorff's tubes and stored at$40^{\circ} \mathrm{C}$ till used to avoid repeated freeze-thaw cycles in different assays, except aliquots of total peroxide were assayed quickly after homogenization of tissues for more accurate estimation.

\section{Chemicals}

Absolute ethanol, Ferrous sulphate, Butylated hydroxytoluene, NADPH, EDTA, catalase, hydrogen peroxide, $\mathrm{HCL}, \mathrm{H}_{2} \mathrm{SO}_{4}$, xylenol orange, epinephrine folinciocateau phenol, and hydrogen peroxide (Fluka, Merk and Sigma-Aldrich Companies). All other chemicals were of the highest quality available.

\section{Biochemical assays}

Superoxide dismutase (SOD) activity was determined based on its ability to inhibit the autoxidation of epinephrine in alkaline conditions as described by Misra and Fridovich (1972). Sigma SOD enzyme was used as standard. SOD was measured at $480 \mathrm{~nm}$. Total peroxides (TP) was assayed
NeemAzal-T/S was emulsified by using emulsifier agent (SiSi-6) and the emulsifiable concentrate was $50 \%$.

\section{Design of the experiment}

At the end of the experiment, blood sample was taken from the caudal peduncle by suction, and then fish were sacrificed and were dissected. Sample of gills (at right side) were excised. Ten percentage homogenates (w/v) were made in phosphate buffer ( $\mathrm{pH}$ 7.4) using homogenizer (model IKA- WERKE, D118 BASIC, Germany). Then, homogenates were centrifuged at 5,000 rpm for $15 \mathrm{~min}$ to separate the homogenate. Preparation of erythrocyte hemolysate: immediately after collection, blood samples were centrifuged at $3,000 \mathrm{rpm}$ for $15 \mathrm{~min}$ at $4^{\circ} \mathrm{C}$. The plasma and buffy coats were removed by aspiration. The sediment containing blood cells was washed three times by resuspending in isotonic phosphate-buffered saline, followed by re-centrifugation and removal of the supernatant fluid and the buffy coats. The crude red cells

based on the method of Harma et al., (2005). Catalase activity was assayed by the method of Aebi (1974). The reaction mixture contained $50 \mathrm{Mm}$ phosphate buffer $(\mathrm{Ph}$ 7.0) and $50 \mathrm{Mm} \mathrm{H}_{2} \mathrm{O}_{2}$. The reaction rate was measured at $240 \mathrm{~nm}$. Sigma catalase enzyme was used as standard. The reagent was prepared as follows: $9.8 \mathrm{mg}$ Ammonium Ferrous sulphate was added to $10 \mathrm{ml}$ of $250 \mathrm{Mm} \mathrm{H}_{2} \mathrm{SO}_{4}$. This solution was added to $90 \mathrm{ml}$ absolute methanol containing $79.2 \mathrm{mg}$ butylated hydroxytoluene and then 7.6 mg xylenol orange was dissolved. The absorbance was measured after incubation of homogenate sample with the reagent for $30 \mathrm{~min}$ at $560 \mathrm{~nm} . \mathrm{H}_{2} \mathrm{O}_{2}$ was used as standard Haemoglobin $(\mathrm{Hb})$ content was also, assayed by cyanomethaemoglobin method (Jain, 1986). Blood glucose was determined by the method of Barham and Trinder (1972). Total protein in the tissue homogenates was measured using the folin reagent according the method of Lowry et al.(1951). All assays were performed in triplicate. Spectrophotometer, UNICAM, Helios Gamma, No. UVG 060609, England was used for all biochemical assays.

Table 1: Design of fish groups with different treatments.

\begin{tabular}{|c|c|c|c|c|c|c|c|c|c|c|c|}
\hline & \multicolumn{3}{|c|}{ After 10 days } & \multicolumn{3}{|c|}{ After 20 days } & \multicolumn{5}{|c|}{ After 30 days } \\
\hline & \multicolumn{3}{|c|}{ Group1 } & \multicolumn{3}{|c|}{ Group2 } & \multicolumn{5}{|c|}{ Group3 } \\
\hline Each SG was 8 fish & SG1 & SG2 & SG3 & SG1 & SG2 & SG3 & SG1 & SG2 & SG3 & SG4 & SG5 \\
\hline Cont & + & & & + & & & + & & & & \\
\hline NO1 & & + & & & + & & & + & & & \\
\hline $\mathrm{NO} 2$ & & & + & & & + & & & + & & \\
\hline $\mathrm{NO} 1+\mathrm{LS}$ & & & & & & & & & & + & \\
\hline $\mathrm{NO} 1+\mathrm{LS}$ & & & & & & & & & & & + \\
\hline
\end{tabular}

NA1: NeemAzal of 16 PPM, NA2: NeemAzal of 32 PPM, SG: subgroup, Healthy six fish were chosen from each SG. $n=6$.

\section{Statistical analysis}

The data were expressed as mean + SEM. The results were analyzed statistically using column statistics and one way ANOVA with Newman-Keuls Multiple comparison test as a post-test. These analyses were carried out using computer statistics prism 3.0 packages (Graph pad software, Inc, San Diego. (A. USA). The minimum level of statistical significance was set at $\mathrm{P}<0.05$. 


\section{Result}

\section{LC50 of NeemAzal -T/S at 96hrs exposure in tilapia fish}

Toxicity test showed that 96-hr LC50 values of Oreochromis niloticus was $160 \mathrm{mg} / \mathrm{l}$ for NeemAzal -T/S. Clinical signs were manifested in the form of nervous manifestations, abnormal swimming behavior in the form of erratic swimming prior to mortality, abnormal skin discoloration. The fish exhibited respiratory distress (such as gasping air). The postmortem findings revealed congestion and haemorrhages in all internal organs in addition to pale anemic gills.

\section{Gills}

It was noticeable that Catalase (CAT) activity in fish erythrocytes is five to seven-folds higher than in gills in control groups (Table 2). Data obtained here in (Table 2) show that the NA1 (low NeemAzal dose) and NA2 (high dose) significantly diminished CAT activity in gill after 30 days $v s$ control. At the 10 and 20 days, CAT activity showed significant rise in NA2 fish group, and marked drop in NA1 group.

Table 2 shows that the activity of erythrocytic SOD was 1.5 to 1.7-fold higher than in gills in control fish group. Data shows fluctuations in the levels of SOD activities at the 10 and 20 days after exposure of fish to both NA doses were recorded; this was followed by marked decreases at the 30 days in response to NA1 and NA2. Regarding oxidative stress bioindicator, both NA1 and NA2 significantly enhanced total peroxide (TP) at all periods corresponding to control values. The destructive effect of NA on gills increased with increasing time and of exposure as well as the dose used (Table2).

Lupine seed supplementation (LS) could curtail the perturbation of antioxidant enzyme activities as well as destructive biomarker, total peroxide (TP). LS improved CAT and SOD activities in fish exposed to NA1 and NA2. In addition, LS improved the TP levels in fish gills exposed to NA1 and NA2 (Table 2).

\section{Erythrocytes}

Table 3 shows that NA2 markedly decreased the activities of catalase (CAT) and SOD enzymes at all periods, while the NA1 significantly increased SOD activity at all periods. Concerning destructive bioindicator, TP was significantly increased at all periods of NA1 and NA2 (Table 3)

The enhancing effect of NA on TP and its lowering effect on enzymatic antioxidants; CAT and SOD activity in erythrocytes were took place (Table 3 ). In the fish-exposed to NA1 or NA2 and supplemented with lupine, there were a significant recoveries in the levels of erythrocytic TP, activities of CAT and SOD compared with corresponding control values.

Table 2. Effect of lupine supplementation (LS) on catalase (CAT), superoxide dismutase (SOD) activities and total peroxide in gills of the Nile fish Oreochromis niloticus contaminated with NeemAzal (doses:NA1= 16 and NA2 =32 ppm).

\begin{tabular}{|c|c|c|c|c|c|c|c|c|c|c|c|}
\hline \multirow[b]{2}{*}{ Gills } & \multicolumn{3}{|c|}{ After 10 days } & \multicolumn{3}{|c|}{ After 20 days } & \multicolumn{5}{|c|}{ After 30 days } \\
\hline & Cont & NA1 & NA2 & Cont & NA1 & NA2 & Cont. & NA1 & NA2 & NA1+L & NA2+L \\
\hline $\begin{array}{l}\text { SOD } \\
\text { activity } \\
\mathrm{U} / \mathrm{min} / \mathrm{mg} \\
\text { protein }\end{array}$ & $\begin{array}{l}3.88^{\mathrm{a}} \\
\pm 0.49\end{array}$ & $\begin{array}{l}4.75^{\mathrm{b}} \\
\pm 0.30\end{array}$ & $\begin{array}{l}3.51^{\mathrm{a}} \\
\pm 0.44\end{array}$ & $\begin{array}{l}4.31^{\mathrm{a}} \\
\pm 0.30\end{array}$ & $\begin{array}{l}3.80^{\mathrm{a}} \\
\pm 0.29\end{array}$ & $\begin{array}{c}6.43^{\mathrm{b}} \\
\pm 0.27\end{array}$ & $\begin{array}{l}4.03 a \\
\pm 0.31\end{array}$ & $\begin{array}{l}3.47^{\mathrm{a}} \\
\pm 0.25\end{array}$ & $\begin{array}{l}2.23^{b} \\
\pm 0.21\end{array}$ & $\begin{array}{l}3.96^{\mathrm{a}} \\
\pm 0.38\end{array}$ & $\begin{array}{l}3.69^{\mathrm{a}} \\
\pm 0.28\end{array}$ \\
\hline $\begin{array}{l}\text { total } \\
\text { Peroxide } \\
\mathrm{nMol} / \mathrm{mg} \\
\text { protein }\end{array}$ & $\begin{array}{l}17.61^{\mathrm{a}} \\
\pm 0.28\end{array}$ & $\begin{array}{l}40.88^{b} \\
\pm 3.11\end{array}$ & $\begin{array}{l}33.26^{\mathrm{c}} \\
\pm 1.75\end{array}$ & $\begin{array}{l}22.79^{\mathrm{a}} \\
\pm 1.02\end{array}$ & $\begin{array}{l}61.88^{\mathrm{b}} \\
\pm 2.31\end{array}$ & $\begin{array}{l}51.28^{\mathrm{c}} \\
\pm 2.18\end{array}$ & $\begin{array}{l}19.31^{\mathrm{a}} \\
\pm 1.16\end{array}$ & $\begin{array}{c}30.36^{\mathrm{b}} \\
\pm 1.89\end{array}$ & $\begin{array}{l}42.16^{\mathrm{c}} \\
\pm 2.36\end{array}$ & $\begin{array}{l}21.9^{\mathrm{ad}} \\
\pm 1.58\end{array}$ & $\begin{array}{c}17.18^{\mathrm{ad}} \\
\pm 1.43\end{array}$ \\
\hline $\begin{array}{l}\text { CAT } \\
\text { activity } \\
\text { U/min/mg } \\
\text { protein }\end{array}$ & $\begin{array}{l}2.08^{\mathrm{a}} \\
\pm 0.14\end{array}$ & $\begin{array}{c}1.68^{\mathrm{a}} \\
\pm 1.00\end{array}$ & $\begin{array}{l}3.66^{\mathrm{b}} \\
\pm 0.25\end{array}$ & $\begin{array}{l}2.30^{\mathrm{a}} \\
\pm 0.04\end{array}$ & $\begin{array}{l}2.02^{\mathrm{a}} \\
\pm 0.19\end{array}$ & $\begin{array}{l}4.31^{\mathrm{b}} \\
\pm 0.29\end{array}$ & $\begin{array}{l}2.13^{\mathrm{a}} \\
\pm 0.16\end{array}$ & $\begin{array}{l}1.45^{\mathrm{b}} \\
\pm 0.17\end{array}$ & $\begin{array}{l}1.05^{\mathrm{c}} \\
\pm 0.06\end{array}$ & $\begin{array}{l}1.82 \mathrm{a}^{\mathrm{b}} \\
\pm 0.14\end{array}$ & $\begin{array}{l}1.77^{\mathrm{ab}} \\
\pm 0.19\end{array}$ \\
\hline
\end{tabular}

Data are presented as means \pm SEM. Columns in each period with different letters differ significantly $(\mathrm{P}<0.05)$, while those with the same letters do not differ significantly. NA: NeemAzal, L: Lupine, $\mathrm{n}=6$. 
Table 3: Effect of lupine supplementation (LS) on catalase (CAT), superoxide dismutase (SOD) activities and total peroxide in blood erythrocytes of the Nile fish Oreochromis niloticus contaminated with NeemAzal (doses:NA1=16 and NA2 =32 ppm ).

\begin{tabular}{|c|c|c|c|c|c|c|c|c|c|c|c|}
\hline \multirow[b]{2}{*}{ Erythrocytes } & \multicolumn{3}{|c|}{ After 10 days } & \multicolumn{3}{|c|}{ After 20 days } & \multicolumn{5}{|c|}{ After 30 days } \\
\hline & Cont & NA1 & NA2 & Cont & NA1 & NA2 & Cont. & NA1 & NA2 & $\mathrm{NA} 1+\mathrm{L}$ & $\mathrm{NA} 2+\mathrm{L}$ \\
\hline $\begin{array}{l}\text { SOD activity } \\
\mathrm{U} / \mathrm{min} / \mathrm{mg} \mathrm{Hb}\end{array}$ & $\begin{array}{l}5.5^{\mathrm{a}} \\
\pm 0.70\end{array}$ & $\begin{array}{l}6.68^{\mathrm{a}} \\
\pm 0.22\end{array}$ & $\begin{array}{l}4.32^{\mathrm{b}} \\
\pm 0.38\end{array}$ & $\begin{array}{l}9.52^{\mathrm{a}} \\
\pm 0.41\end{array}$ & $\begin{array}{l}12.48^{\mathrm{b}} \\
\pm 0.72\end{array}$ & $\begin{array}{l}5.2^{\mathrm{c}} \\
\pm 0.19\end{array}$ & $\begin{array}{l}6.36^{\mathrm{a}} \\
\pm 0.51\end{array}$ & $\begin{array}{l}8.02^{\mathrm{b}} \\
\pm 0.27\end{array}$ & $\begin{array}{l}3.46^{\mathrm{cd}} \\
\pm 0.29\end{array}$ & $\begin{array}{l}4.92^{\mathrm{d}} \\
\pm 0.46\end{array}$ & $\begin{array}{l}4.64^{\mathrm{d}} \\
\pm 0.41\end{array}$ \\
\hline $\begin{array}{l}\text { total Peroxide } \mathrm{nMol} / \mathrm{mg} \\
\mathrm{Hb}\end{array}$ & $\begin{array}{l}4.51^{\mathrm{a}} \\
\pm 0.44\end{array}$ & $\begin{array}{l}5.03^{\mathrm{a}} \\
\pm 0.51\end{array}$ & $\begin{array}{l}9.57^{\mathrm{b}} \\
\pm 0.52\end{array}$ & $\begin{array}{l}7.02^{\mathrm{a}} \\
\pm 0.52\end{array}$ & $\begin{array}{l}9.8^{\mathrm{b}} \\
\pm 0.57\end{array}$ & $\begin{array}{l}9.8^{c} \\
\pm 0.41\end{array}$ & $\begin{array}{l}6.06^{\mathrm{a}} \\
\pm 0.45\end{array}$ & $\begin{array}{l}9.8^{\mathrm{b}} \\
\pm 0.22\end{array}$ & $\begin{array}{l}16.39^{c} \\
\pm 0.43\end{array}$ & $\begin{array}{l}8.22^{\mathrm{d}} \\
\pm 0.72\end{array}$ & $\begin{array}{l}6.46^{\mathrm{a}} \\
\pm 0.49\end{array}$ \\
\hline $\begin{array}{l}\text { CAT activity } \\
\mathrm{U} / \mathrm{min} / \mathrm{mg} \mathrm{Hb}\end{array}$ & $\begin{array}{l}16.6^{\mathrm{ab}} \\
\pm 1.69\end{array}$ & $\begin{array}{l}21^{\mathrm{a}} \\
\pm 1.48\end{array}$ & $\begin{array}{l}14.12^{\mathrm{b}} \\
\pm 0.87\end{array}$ & $\begin{array}{l}13.23^{\mathrm{a}} \\
\pm 1.39\end{array}$ & $\begin{array}{l}15.56^{\mathrm{a}} \\
\pm 1.59\end{array}$ & $\begin{array}{l}6.44^{\mathrm{c}} \\
\pm 0.41\end{array}$ & $\begin{array}{l}12.36^{\mathrm{ab}} \\
\pm 1.00\end{array}$ & $\begin{array}{l}10.74^{\mathrm{a}} \\
\pm 0.89\end{array}$ & $\begin{array}{l}6.9^{\mathrm{d}} \\
\pm 0.57\end{array}$ & $\begin{array}{l}8.55^{\mathrm{cd}} \\
\pm 0.60\end{array}$ & $\begin{array}{l}10.23^{\mathrm{bc}} \\
\pm 0.72\end{array}$ \\
\hline
\end{tabular}

Data are presented as means \pm SEM. Columns in each period with different letters differ significantly $(\mathrm{P}<0.05)$, while those with the same letters do not differ significantly. NA: NeemAzal, L: Lupine, $n=6$.

Table 4: Effect of lupine supplementation (LS) on blood sugar (glycemia) in the fish Oreochromis niloticus contaminated with neemazal (doses: NA1 $=16$ and NA2 $=32 \mathrm{ppm}$ ).

\begin{tabular}{|c|c|c|c|c|c|}
\hline & Control & NA1 & NA2 & NA1+ LS & NA2+ LS \\
\hline Blood sugar mg/D1 & 18.40 & $40.40^{*}$ & $31.00^{*}$ & 25.40 & 23.00 \\
& \pm 1.33 & \pm 2.49 & \pm 0.98 & \pm 1.61 & \pm 1.39 \\
& & & & & \\
\hline
\end{tabular}

Data are presented as means \pm SEM. *: Significant at $\mathrm{P}<0.5$.

\section{Glycemia}

Table 4 shows that at the third week, low and high doses of NA markedly increased blood sugar levels in tilapia. LS in the fish exposed to NA, could dampens down the hyperglycemic levels showing hypoglycemic power.

\section{Discussion}

The intoxicated fish were aggregated at the corner of the aquarium resting at the bottom and frequently come to the surface followed by heavy breathing with stronger opercular movements and loss of equilibrium. Also the over secretion of mucus was observed on the fishes treated to pesticide. This has been observed in fishes treated with other pesticides (Reza and Gholamreza, 2012).

Toxicity of neem-based products to different fish species is difficult to compare as they are influenced by various factors such as light and water. Moreover, the toxicity also depends upon solvents and the emulsifiers used for formulating the materials (Wan et al., 1996) as well as on the species differences. To assess the adverse effects of the NeemAzal - T/S insecticide on tilapia fish experimentally, LC50 was detected and recorded as $160 \mathrm{mg} / \mathrm{l}$. This result is more or less similar to that of Stewart (1998).

Gills, which are key organs for the direct action of pollutants in the aquatic environment (Sara et al., 2014). Gills are considered the most valuable organ to external pollutants owing to their direct contact with water, facilitating the lamellar epithelia penetration and ingress into blood circulation (Kellya and Janz, 2009). Inflammatory changes, such as swelling, lifting of lamellar epithelium and hyperplasia have also been noted in the gill lamellae of various fish species following exposure to insecticides (Neelima et al., 2015).

Freshwater fish Oreochromis niloticus exposed to neem seed oil concentrations exhibited damaged gill, liver and kidney tissue (Ashraf et al., 2014). Exposure to low concentrations of the crude extract of $A$. indica delayed the growth of this cichlid fish Tilapia zillii (Omoregie and Okpanachi, 1992). The impact of Azadirachtin caused an initial increase of the hyperplasia, vacuolization of mucus cells, telengiectasia (clumping of blood vessels), opercula ventilation rates, and respiratory distress in the gills of the fish Glossogobius giuris (Mamatha and Mohan, 2014).

The present study showed that the high dose NeemAzal (NA) (1/5 LC50: 32 PPM) markedly decreased the activity of catalase (CAT) enzyme in gills after NA for 20 and 30 days. Low dose of NeemAzal (NA1: 1/10 LC50: 16 PPM) and (NA2: 1/5 LC50: 32 PPM) significantly diminished CAT activity in gill at the 30 days. At the 10 and 20 days, CAT activity showed significant rise in NA2 fish group, and marked drop in NA1 group.

Also, Data shows fluctuations in the levels of SOD activities at the 10 and 20 days after exposure of fish to both NA doses were recorded; this was followed by marked decreases at the 30 days in response to NA1 and NA2. In turn, both doses of NA significantly enhanced the destructive oxidative biomarker; total peroxide (TP) at all periods corresponding to control values. This result was accompanied with a severe hyperglycemia at the 30 days in response to high and low doses of NA in tilapia.

Moreover, this hyperglycemic effect of NA contamination may be associated with low cellular uptake of glucose. The 
lowering effect of NA toxicity on CAT activity may be attributed to disturbances in glucose tissue uptake, low level of Glucose-6-phosphate dehydrogenase (G6PDH), low production of NADPH or/and over production of reactive oxygen species (ROS). This concept based on G6PDH enzyme of the pentose phosphate pathway, plays a crucial role in modulating antioxidant defenses where it participate in production of NADPH necessary for CAT activity (Leopold and Loscalzo, 2000). Deltamethrin significantly inhibited the trout erythrocyte G6PD enzyme activity (Murat et al., 2009).

The accentuated generation of ROS due to the introduction of the pesticides (Ates et al., 2008 and Anilava and Abhik, 2014). The rise in blood sugar for several hours for few days severely increased oxidative stress in body tissues due to overproduction of ROS (Be'meur et al., 2007). Also, neem oil was found to reduce the oxygen uptake of fish fingerlings and causes mortality at a faster rate (Mondal et al., 2007).

Hypoxia induced oxidative stress in fish (Lushchak et al 2005; Neelima et al., 2015) and in mice (El-Sokkary etal., 2006). Based on these findings, inhibition of SOD activity showed in the fish-exposed to NA may resulted from: high utilization of enzyme due to marked flux of ROS, oxidative damage of gills probable facilitated $\mathrm{Cu}$ elimination or/ and anoxia as well as hyperglycemia- induced exceeded ROS. This concept is in harmony with the great rise in TP, which is mainly represented by $\mathrm{H}_{2} \mathrm{O}_{2}$ and its derivatives. This is in agreement with that reported by Bagnyukova etal.(2005) who reported that the tissues of xenobiotic detoxification are considered to be powerful ROS generators. In addition, fish gill is in close contact with environmental water contaminants, being the main absorption organ for those aquatic toxicants, facilitating their fast absorption and contact with phagocytes (Neelima et al., 2015).

The current study showed that NA2 contamination (high dose) significantly diminished CAT activity in erythrocytes at all periods, while the lowering effect of the low dose (NA1) on this activity was appeared after 30 days. In addition, NA2 significantly decreased activity of superoxide dismutase (SOD) vs control at all periods, while the NA1 significantly increased SOD activity at all periods. Also, erythrocytic destructive biomarker; TP was significantly increased at all periods of NA1 and NA2 exposure. RBCs are considered prime targets for oxidative injury, mainly because of their unique biological structure which contains high concentrations of membrane polyunsaturated fatty acids (PUFAs) (Arranz et al., 2013).

The inhibiting effect of NA on antioxidant enzyme activities of CAT and SOD accompanied with its enhancing effect on TP levels may attributed to the overproduction of ROS, following by excessive production of $\mathrm{H}_{2} \mathrm{O}_{2}$ in erythrocytes of tilapia. Excessive production of ROS usually results from excitation of $\mathrm{O} 2$ to form singlet oxygen or from the transfer of one, two or three electrons to $\mathrm{O} 2$ to form a superoxide radical (O2 -), hydrogen peroxide $\left(\mathrm{H}_{2} \mathrm{O}_{2}\right)$ or a hydroxyl radical $\left(\mathrm{HO}^{\circ}\right)$, respectively (AlSalahy, 2011). The erythrocytic role as $\mathrm{O} 2$ and $\mathrm{CO}_{2}$ transporter is under constant exposure of free radicals (Harvey, 1997). It has been found that decreased NADPH levels were correlated with a loss of catalase activity in human erythrocytes (Gaetani et al., 1989). It was concluded that in hypoxia, increased $\mathrm{Hb}$ autoxidation augments superoxide production in RBCs. Consequently, RBCs release $\mathrm{H}_{2} \mathrm{O}_{2}$ (Brill etal., 2012).

The authors added that $\mathrm{H}_{2} \mathrm{O}_{2}$ escaped the $\mathrm{RBC}$ antioxidant system and diffused to the adjoining tissues. Also, it was reported that in hypoxia, red blood cells (RBCs) produces ROS that diffuse to endothelial cells of adjoining blood vessels (Brill et al., 2012). In turn, pesticide including neem oil inducing hypoxia and tissue anoxia (Pimpão et al., 2007; Mondal et al., 2007). However, unlike the non-nucleated mammalian red blood cells, fish erythrocytes possess very large nuclei, which may occupy about $29 \%$ of the cell volume (Wilhelm-Filho et al., 1992).

In addition, hyperglycemia generate ROS through diverse pathways, leading to oxidative stress in a variety of tissues (Brownlee, 2003). Supporting these finding, the current data showed that there are significant positive correlations between oxidative damage marker; TP and the rise in glycemic level induced by both NA1 and NA2 contamination in erythrocytes and in gills. Hyperglycemia is one of the important factors to increase ROS, lipid peroxidation causing the depletion of the antioxidant defense status in various tissues of rats (Reddy et al., 2009). From these findings, it could suggests that NA toxicity increase $\mathrm{H}_{2} \mathrm{O}_{2}$ in erythrocytes and this was facilitated in fish where gills were in close contact with water the source of contamination particularly gills are rich in blood vessels. This suggests that $\mathrm{RBCs}$ filled with $\mathrm{H}_{2} \mathrm{O}_{2}$ in fish-exposed with NA may participate in distribution and spreading of free radicals counteracting the antioxidant defense system in all tissue organs of the fish, Oreochromis niloticus.

Seeds of lupine (Lupinus termis) have a hypoglycemic action in diabetic animals (Marzouk et al., 2013). Also, hypoglycemic effect of lupine was recorded in fish either treated by alloxan or loaded glucose (Mahmoud and AlSalahy, 2005). In addition, lupine seeds have an ameliorating effect on glucose tolerance test in the fish Clarias gariepinus (Al-Salahy and Mahmoud, 2004). It had been suggested that lupine seeds might have higher antioxidant activity and contains a high amount of arginine, aspartate and glycine (Oomah et al., 2006), tocopherols (Venskutonis and Kraujalis, 2013).

Both arginine and tocopherol are considered as antioxidants (Gupta et al., 2005) and may enhance lupine seeds to be free 
radical scavenger and more efficient as an antioxidant. The present study showed that lupine seed supplementation (LS) reversed the adverse effect or at least induced improvement effect in both gills and erythrocytes of NA on antioxidants; CAT and SOD as well as on oxidative stress parameter, TP. This result may be partly due to the hypoglycemic role of lupine which showed 30 days after NA exposure. This may stimulate cellular uptake of glucose and probably normalizing NADPH necessary for CAT activity. Also, some constituents of lupine are considered as antioxidants and acts as free radical scavenger improving the complications of hypoxia which perhaps resulted from oxidative damage on gills. Similarly, it was found that melatonin as antioxidant could improve the oxidative damage in mice-subjected to hypoxia (El-Sokkary et al., 2006).LS able to improve the TP levels in gills and erythrocytes exposed to NA1 and NA2. This result suggests a lowering effect of LS on tissue containing excess of $\mathrm{H}_{2} \mathrm{O}_{2}$ and its derivatives confirming its antioxidant role.

In conclusion, NA is very harmful on non-target organism such as fresh water fish particularly these fish usually found near the agricultural areas. In turn, addition of lupine seeds in fish diet can protect against some pests-induced oxidative stress.

\section{Acknowledgements}

The author would like to acknowledge Dr. kamal A. Attia, professor of animal physiology,Biology Department, University college , Umm -Alqura University ,Saudia Arabia for his kind advices during the present study.

\section{Reference}

Al-Salahy MB (2011) Physiological studies on the effect of copper nicotinate $(\mathrm{Cu}-\mathrm{N}$ complex) on the fish, Clarias gariepinus, exposed to mercuric chloride. Fish physiology and biochemistry, 37(3): 373-385.

Al-Salahy MB and Mahmoud AB (2004) The ameliorating effects of lupine and fenugreek seeds on the kidney of the fish Clarias gariepinus treated with alloxan and glucose. Egypt. J. Zool. 43: 381 - 398.

Anilava K. and Abhik G (2014) Biomarkers of Type II Synthetic Pyrethroid Pesticides in Freshwater Fish. BioMed Research International.

Arranz L, Naudí A, De la Fuente M and Pamplona R (2013) Exceptionally old mice are highly resistant to lipoxidationderived molecular damage. Age 35(3): 621-635.

Ashraf AM, Alkhateib Y, Hossam H and Mohammad M (2014) The protective role of copper nicotinate and vitamin $\mathrm{E}$ against neem seed oil induced oxidative stress and histopathological changes in Nile Tilapia (Oreochromis niloticus, Linnaeus, 1758). Egypt. J. Aquat. Biol. \& Fish.18 (3): 1- 19.

Ates B, Orun I, Talas Z, Durmaz G and Yilmaz I (2008) Effects of sodium selenite on some biochemical and hematological parameters of rainbow trout (Oncorhynchus mykiss Walbaum, 1792) exposed to $\mathrm{Pb}^{2+}$ and $\mathrm{Cu}^{2+}$. Fish Physiology and Biochemistry, 34 (1): 53-59.

Bagnyukova T, Storey K. and Lushchak V (2005) Adaptive response of antioxidant enzymes to catalase inhibition by aminotriazole in goldfish liver and kidney. Comparative Biochemistry and Physiology Part B: Biochemistry and Molecular Biology, 142(3): 335-341.

Barham D and Trinder P (1972) An improved colour reagent for the determination of blood glucose by the oxidase system. Analyst, 97(1151): 142-145.

Be'meur C, Ste-Marie L and Montgomery J (2007) Review Increased oxidative stress during hyperglycemic cerebral ischemia. Neurochem Inter. 50,

Bhat A, Bhat A, Vishwakarma S, Verma A and Saxena G(2012) A Comparative Study on the Toxicity of a Synthetic Pesticide, Dichlorvos and a Neem based Pesticide, NeemOn to Labeo rohita (Hamilton). Current World Environment, 7(1): 157-161.

Boateng J, Verghese M, Walker L and Ogutu S (2008) Effect of processing on antioxidant contents in selected dry beans (Phaseolus spp. L.). LWT-Food Science and Technology, 41(9):1541-1547.

Boeke S, Boersma M, Alink G, van J, Van Huis L, Marcel M and Ivonne M (2004) Rietjens Safety evaluation of neem (Azadirachta indica) derived pesticides. $J$. Ethnopharmacol. 94: 25-41.

Brill A, Fuchs T, Savchenko A, Thomas G, Martinod K., De Meyer S and Wagner D (2012) Neutrophil extracellular traps promote deep vein thrombosis in mice. Journal of Thrombosis and Haemostasis, 10(1): 136-144.

Brownlee M (2003) A radical explanation for glucose-induced beta cell dysfunction, J. Clin. Invest. 112: 1788-1790.

Chromcova L, Blahova J, Zivna D, Plhalova L, Casuscelli di Tocco F, Divisova D, Prokes M, Faggio C, Tichy F and Svobodova Z (2015) NeemAzal T/S - toxicity to earlylife stages of common carp (Cyprinus carpio L.). Veterinarni Medicina, 60, (1): 23-30.

David M and Kartheek R (2014) Sodium cyanide induced Histopathological changes in kidney of fresh water fish Cyprinus carpio under sublethal exposure. Int. J. Pharma. Chem. Biol. Sci. 4(3): 634- 639.

Davoodi R and Abdi G (2012) Comparative study on the acute toxicity of synthetic pesticides, permethrin $25 \%$ and monocrotophos $36 \%$, and neem-based pesticide, neem gold EC $0.03 \%$, to Juvenile Cyprinus carpio Linn. J Biol Environ Sci, 6(16): 105-108.

Deka S and Mahanta R (2012) A Study on the Effect of Organophosphorus Pesticide Malathion on Hepato- Renal and Reproductive Organs of Heteropneustes fossilis (Bloch). Sci. Probe. 1(1): 1-13.

Elenka Georgieva, Stela Stoyanova Iliana Velcheva and Vesela Yancheva (2014) Histopathological Alterations in Common Carp (Cyprinus carpio L.) Gills Caused by Thiamethoxam. Braz. Arch. Biol. Technol.57 (6) Curitiba Nov./Dec. 
Elissandra UW, Thiago RM, Joaquim GM and Cláudia BR (2007) Acute lethal and sublethal effects of neem leaf extract on the neotropical freshwater fish Prochilodus lineatus. Comparative Biochemistry and Physiology Part C: Toxicology \& Pharmacology, 145 (2): 236-244.

El-Missiry MA, Othman AL and Amer MA (2004) L-Arginine ameliorates oxidative stress in alloxan-induced experimental diabetes mellitus, J. Appl. Toxicol. 24: 9397.

El-Sokkary GH, Khidr BM and Younes HA (2006) Role of melatonin in reducing hypoxia-induced oxidative stress and morphological changes in the liver of male mice. Euro. J. Pharmacol. 540: 107-114.

EPA (Environmental Protection agency) (1985) Methods for measuring the acute toxicity of effluents to freshwater and marine organisms (3rd edition). EPA/600/485/013.Environmental Monitoring and Support Laboratory, Cincinnati, OH, USA.

Gaetani GF, Galiano S, Canepa L, Ferraris AM and Kirkman HN (1989) Catalase and glutathione peroxidase are equally active in detoxification of hydrogen peroxide in human erythrocytes. Blood. 73: $334-339$.

Gupta V, Gupta A, Saggu S, Divekar HM, Grover S K. and Kumar R (2005) Anti-stress and Adaptogenic Activity of LArginine Supplementation, Oxford Journals Medicine Evidence-based Compl. and Alt. Medicine 2: 93-97.

Gutteridge JMC (1995) Lipid peroxidation and antioxidants as biomarkers of tissue damage. Clin. Chem. 41: 1819-1828.

Hanem FK (2012) Prospects of Botanical Biopesticides in Insect Pest Management. RESEARCH ARTICLE. (3) 12.

Harma M, Harma M and Erel O (2005) Measurement of the total antioxidant response in preeclampsia with a noval automated method. Euro. J. Obst. Gyn. Reprod. Biol., 118: $47-51$.

Harvey JW (1997) The erythrocyte: Physiology, Metabolism and Biochemical disorders. In: Kaneko, J.J., Harvey, J.W., Bruss, M.L. (Eds.), Clinical Biochemistry of Domestic Animals. fifth ed. Academic press, London, pp. 157-203.

Jain NC (1986) Hematologic techniques. In: Jain, N.C. (ed.), Schalm's Veterinary Hematology, fourth ed., Lea and Febiger, Philadelphia, pp. 20-86.

Jain NC (1993) Erythrocyte physiology and changes in disease, In: Essentials of Veterinary Hematology. Lea \& Febiger, Philadelphia pp. 133-158.

Kellya JM and Janz DM (2009) Assessment of oxidative stress and histopathology in juvenline northern pike (Esoxlucius) in habiting lakes downstream of a uranium mill. Aquat. Taxicol. 92: 240-249.

Kiefmann R, Rifkind JM, Nagababu E and Bhattacharya J (2008) Red blood cells induce hypoxic lung inflammation. Blood. 111: 5205-5214.

Kumar S, Raman R, Kumar K., Pandey P, Kumar N, Mallesh B and Kumar A (2013) Effect of azadirachtin on haematological and biochemical parameters of Argulus- infested goldfish Carassius auratus (Linn. 1758). Fish physiology and biochemistry, 39(4): 733-747.

Leopold JA and Loscalzo J (2000) Cyclic strain modulates resistance to oxidant stress by increasing G6PDH expression in smooth muscle cells, Am. J. Physiol. 279: H2477-H2485.

Li W, Gao Y, Zhao J and Wang Q (2007) Phenolic, flavonoid, and lutein ester content and antioxidant activity of 11 cultivars of Chinese marigold. Journal of Agricultura and Food Chemistry, 55(21): 8478-8484.

Lowry OH, Rosenbrough NG, Farr AL and Randall RJ (1951) Protein measurement with folin phenol reagent, J. Biol. Chem. 193: 265-275.

Lushchak VI (2011) Environmentally induced oxidative stress in aquatic animals. Aquatic Toxicology, 101(1): 13-30.

Lushchak VI, Bagnyukova TV, Lushchak OV, Storey JM and Storey K.B (2005) Hypoxia and recovery perturb free radical processes and antioxidant potential in common carp (Cyprinus carpio) tissues. Inter. J. Biochem. Cell Biol. 37: 1319-1330.

Mahmoud AM and Al-Salahy MB (2005) Physiological and histological studies on the effect of lupine seeds on the fish Clarias lazera treated with glucose and alloxan. Fish Physiol. Biochem. 30: 213-229.

Mamatha P and Mohan M (2014) Detection of biopesticide Azadirachtin and analysis of gill tissues of the fish Glossogobius giuri using HPCL. Advances in Forestry Science, 1(3): 83-88.

Marzouk M, Soliman AM and Omar TY (2013) Hypoglycemic and antioxidative effects of fenugreek and termis seeds powder in streptozotocin-diabetic rats. Eur Rev. Med Pharmacol Sci, 17(4): 559-565.

Misra HP and Fridovich I (1972) The role of superoxide anion in the antioxidant of epinephrine and a simple assay for superoxide dismutase, J. Biol. Chem. 247: 3170-3175.

Mondal D, Barat S and Mukhopadhyay MK. (2007) Toxicity of Neem pesticides on a fresh water loach, Lepidocephalichthys guntea (Hamilton Buchanan) of Darjeeling district in West Bengal. J. Environ. Biol. 28: 119-122.

Murat A, Migliavacca E and Hussain S (2009) Modulation of angiogenic and inflammatory response in glioblastoma by hypoxia. PLos One 4: e5947.

Muthukumaravel K, Sivakumar B, Kumarasamy $\mathrm{P}$ and Govindarajan M (2013) Studies on the toxicity of pesticide monocrotophos on the biochemical constituents of the freshwater fish Labeo rohita.Int. J. Curr. Biochem. Biotechnol. 2(10): 20-26.

Neelima P, Cyril L, Arun K., Chandra S, Rao J and Gopala R (2015) Histopathological alterations in Gill, Liver and Kidney of Cyprinus carpio (Linn.) exposed to Cypermethrin (25\%EC). Int. J. Adv. Res. Biol.Sci. 2(2): 34-40. 
Nwani CD, Lakra WS, Nagpure NS, Kumar R, Kushwaha B and Srivastra SK. (2010) Toxicity of the herbicide atrazine: Effects on lipid Peroxidation and activities of Antioxidant Enzymes in the fresh water fish Channa punctatus (Block). Int. J. Environ.Res. Public Health. 7(8): 32983312.

Omoregie E and Okpanachi MA (1992) Growth of Tilapia zillii exposed to sublethal concentrations of crude extracts of Azadirachta indica. Acta Hydrobiol. 34: 281-286.

Oomah B, Tiger N, Olson M and Balasubramanian P (2006) Phenolics and antioxidative activities in narrowleafed lupins (Lupinus angustifolius L.). Plant Foods Hum Nutr. 61:91-97.

Palaniappan P, Nishanth T and Renju V (2010) Bio concentration of zinc and its effect on the biochemical constituents of the gill tissues of lebeo rohita: Ft-IR study. Infrared phys. Technol. 53(2): 103-1 11.

Pastor C, Juan R, Pastor J, Alaiz M and Vioque J (2010) Antioxidant activity in the seeds of four wild lupinus species from southern Spain. Journal of Food Biochemistry, 34(s1): 149-160.

Patil C, Patil S, Salunke B and Salunkhe R (2011) Bioefficacy of Plumbago zeylanica (Plumbaginaceae) and Cestrum nocturnum (Solanaceae) plant extracts against Aedes aegypti (Diptera: Culicide) and nontarget fish Poecilia reticulata. Parasitology research, 108(5): 12531263.

Pimpão CT, Zampronio AR and Silvade Assis HC (2007) Effects of deltamethrin on hematological parameters and enzymatic activity in Ancistrus multispinis (Pisces, Teleostei). Pest Biochem. Physiol. 88: 122-127.

Rao A and Pillala R (2001) The concentration of pesticides in sediments from Kolleru lake in India. Pest Manag. Sci. 57: 620-624.

Reddy SS, Ramatholisamma P, Karuna R and Saralakumari D (2009) Preventive effect of Tinospora cordifolia against high-fructose diet-induced insulin resistance and oxidative stress in male Wistar rats. Food Chem. Toxicol. 47: 22242229.

Reza D and Gholamreza A (2012) Comparative Study on the Acute Toxicity of Synthetic Pesticides, Permethrin 25\% and Monocrotophos 36\%, and Neem-Based Pesticide, Neem Gold EC $0.03 \%$, to Juvenile Cyprinus carpio Linn. J. Biol. Environ. Sci. 6(16): 105-108.

Saeedi F, Roodsari H, Zamini A, Mirrasooli E and Kazemi R (2012)The Effects of Diazinon on Behavior and Some Hematological Parameters of Fry Rainbow Trout (Oncorhynchus mykiss).World J. Fish and Mari. Sci.4(4): 369-375.

Salman A, Shafiq A and Maher A (2013) Demographic changes in Helicoverpa armigera after exposure to neemazal (1\% EC azadirachtin). Crop Protection 50: 30-36.
Sana U and Mohammad J (2015) Ecotoxicology: a review of pesticides induced toxicity in fish. Adv. Anim. Vet. Sci. 3(1): 40-57.

Sara RS, Correia A, Antunes S and Nunes B (2014) Alterations in gills of Lepomis gibbosus, after acute exposure to several xenobiotics (pesticide, detergent and pharmaceuticals): morphometric and biochemical evaluation. Drug and chemical toxicology, (0): 1-7.

Saravanan M, Ramesh M, Malarvizhi A and Petkam R (2011) Toxicity of Neem Leaf Extracts (Azadirachta indica A. Juss) on Some Haematological, Ionoregulatory, Biochemical and Enzymological Parameters of Indian Major Carp, Cirrhinus mrigala. Journal of Tropical Forestry and Environment, 1(1).

Stara A, Machova J and Velisek J (2012) Effect of chronic exposure to simazine on oxidative stress and antioxidant response in common carp (Cyprinus carpio L.). Environmental toxicology and pharmacology, 33(2): $334-$ 343.

Stewart R (1998) Toxicological results of NeemAzal Technical and NeemAzal Formulations. Neem-Ingredients and Pheromones.

Tian WN, Braunstein LD, Apse K., Pang J, Rose M, Tian X and Stanton RC (1999) Importance of glucose-6phospahate dehydrogenase activity in cell death. Am. J. Physiol. 276: C1121- C1131.

Troß R, Jacop Vera Bernauer, E. Hummel and H. Kleeberg ( 1998 ) Azadirachtin A- content and Bio- efficacy in Hair Treated with NeemAzal- Formulations. Practice Oriented Results on Use and Production of Neem-Ingredients and Pheromones. Proceedings of the 7th Workshop.

Ullah R, Zuberi A, Tariq M and Ullah S (2014) Acute Toxic Effects of Cypermethrin on Hematology and Morphology of Liver, Brain and Gills of Mahseer (Tor putitora). Int. J. Agri. Biol. In press.

Venskutonis P and Kraujalis P (2013) Nutritional components of amaranth seeds and vegetables: a review on composition, properties, and uses. Comprehensive Reviews in Food Science and Food Safety, 12(4): 381-412.

Wan M, Watts R, Isman M and Strub R (1996) Evaluation of the acute toxicity to juvenile pacific northwest salmon of azadirachtin, neem extract, and neem-based products. Bulletin of Environmental Contamination and Toxicology, 56(3): 432-439.

Wilhelm-Filho D, Eble GJ, Kassner G, Caprario FX, Dafre AL and Ohira M (1992) Comparative hematology in marine fish. Comp. Biochem. Physiol. Part A. 102:311-321.

Winkaler E U, Santos TRM, Machado-Neto JG and Martinez CBR (2007) Acute lethal and sublethal effects of Neem leaf extract on the neotropical freshwater fish Prochilodus lineatus Comparative Biochemistry and Physiology, Part C. 145: $236-244$. 